\title{
Growth Promotion and Biocontrol Potential of Some Isolated Soil Fungi against Brown Root Rot (Fomes Lamoensis) Disease of Tea in Barak Valley of Assam India
}

\section{Morang P*}

Department of Environmental Science, Pandit Deendayal Upadhayaya Adarsha Mahavidyalaya, Tulungia, Bonagaigaon, India

\section{Research Article}

Volume 3 Issue 5

Received Date: June 11, 2018

Published Date: June 28, 2018

*Corresponding author: Pranjal Morang, Department of Environmental Science, Pandit Deendayal Upadhayaya Adarsha Mahavidyalaya, Tulungia, Bonagaigaon, India, Email: pmorangaus.009@gmail.com

\section{Abstract}

Biological control of plant pathogens involves antagonists are biological agents with the potential to interfere in the life process of the plant pathogens. Therefore these are important inputs for sustainable agricultural. In the experiment, Plant growth promoting fungi (PGPF) were isolated from tea rhizosphere soil. Isolated PGPF were screened for efficacy against the brown root rot pathogen (Fomes lamoensis) in vitro. From the study, four isolates namely Trichoderma viride, $T$. harzianum, T. citrinoviride and Aspergillus niger were exhibited good antagonistic activity against the pathogen. Later, these four selected isolates were examined for their ability to promote growth and disease suppression in pathogen infested soil under nursery conditions. It was found that the treatment in which the tea plants treated with the pathogen only have shown more disease incidence whereas the plant treated in pathogen infested soil with BCF, were found plants longer survival, healthy upto $120^{\text {th }}$ days of observation. Besides disease reduction, It was also observed that plant treated with BCF viz. Trichoderma viride T. harzianum and T. citrinoviride have shown tremendous growth promotion ability in terms of shoot height, root length, biomass of shoot and root etc.

Keywords: Biological Control; Plant Growth Promoting Fungi (PGPF); Brown Root Rot; Growth Promotion, Tea

\section{Introduction}

Brown root rot disease (Fomes lamoensis) is considered as the primary root disease of tea. The disease commonly appears on tea plants growing on sandy soil and is characterized by the presence of brown mycelium on root surface to which soil, sand and stone particles remain encrusted [1]. The fungus is parasitizes 


\section{Open Access Journal of Agricultural Research}

as young as one year to 100 years old tea plants [2]. Yield loss in tea due to pest and diseases varies from 7 to $15 \%$ [3]. Excessive and indiscriminate use of chemicals has posed serious problems of environmental contamination by getting integrated into the food chain. The pathogens are slowly becoming resistant to the chemicals which are known to increase over time [4]. The concept control of diseases has undergone a considerable change in recent years. Biological control is emerging an alternative as to use of chemicals. To develop a sustainable agriculture one should go for eco-friendly crop management methods [5]. Biological control involves suppression of plant diseases by living antagonistic organisms. Soil in the rhizosphere region is inhabited by a large number of microorganisms having the potential to control the diseases biologically [5]. Plant Growth Promoting Rhizobacteria (PGPR) and Plant Growth Promoting Fungi (PGPF) can be used as a suitable alternative for this because of their biocontrol potential [6]. Many attempts have been made to control soil borne plant disease by biological means but few of these attempts have been made successful [7]. These are beneficial organisms that reduce the negative effects of plant pathogens and promote positive responses in the plant. Mechanisms like mycoparasitism, production of antibiotics, and competitions for nutrients in the rhizosphere are responsible for biocontrol ability [8-11]. Most of the early works antagonists related to biocontrol of plant diseases involved Trichoderma spp. During the process of mycoparasitism, the fungi first locates target hyphae by probing with constitutively produced cell wall degrading enzymes (CWDEs) coupled with very sensitive detection of cell wall fragments released from the target fungi [12-14]. Many Trichoderma spp can colonize plant roots of dicots and monocots [12]. During this process Trichoderma hyphae coil around the roots, form appressoria-like structures, and finally penetrate in to the root cortex [15]. Contact with pathogenic and nonpathogenic microorganisms triggers a wide range of defense mechanisms in plants. The present work therefore carried out to develop a fungal formulation for controlling the brown root rot disease of tea besides promoting growth.

\section{Materials and Methods}

\section{Experimental Site}

The investigations were carried out at Rose Kandy Tea Estate, Silchar, Barrack Valley region of Assam, India. The experimental site was situated between $24^{\circ} 42^{\prime} 35.81^{\prime \prime} \mathrm{N}$ latitude and $92^{\circ} 46^{\prime} 8.83$ "E longitude at an elevation of 22 meters with an annual rainfall $2400 \mathrm{~mm}$. Hot and humid summer, dry and cold winter is common features of this region.

\section{Plant}

Three to four year old tea plants (Clone TV 1), obtained from the tea nursery of Rose Kandy Tea Estate was used for the laboratory and nursery studies.

\section{Isolation of Pathogen}

Infected roots were collected from various tea garden of Assam, N.E. India. They were washed with tap water and cut into small pieces. These pieces were surface sterilized with $1 \%$ sodium hypochlorite $\left(\mathrm{NaOCl}_{2}\right)$ for 20 to 40 seconds. Five pieces were placed in each petri dishes containing Potato Dextrose Agar (PDA) medium and incubated at $28 \pm 2{ }^{\circ} \mathrm{C}$ for 7 days. Mycelium grown from inoculated pieces were purified by repeated sub culturing and finally transferred to PDA slants and preserved for further study. Later this isolated pathogen were confirmed as Fomes lamoensis (culture no. 4140) which was procured from Indian Type Culture Collections (ITCC) of Indian Agricultural Research Institute (IARI), New Delhi, India.

\section{Isolation of Plant Growth Promoting Fungi (PGPF)}

PGPF were isolated by serial dilution agar plate technique using PDA medium. Morphologically dissimilar colonies were purified and stored at $4^{\circ} \mathrm{C}$ for further studies.

\section{In Vitro Antagonistic Test}

Actively growing mycelial discs $(6 \mathrm{~mm})$ of $F$. lamoensis were placed in the centre of the Petri plate containing Potato dextrose agar medium. Simultaneously mycelia discs of PGPF's $(6 \mathrm{~mm})$ were also placed near the periphery at diametrically opposite points. All the plates were separately incubated at $25 \pm 1^{\circ} \mathrm{C}$ for 6 days and the growth of the pathogen against the tested antagonists were measured at 2 days intervals. The antagonistic colony interactions were examined thereafter. The kind and degree of antagonism was determined according to the classification of Skidmore and Dickinson (1976). 


\section{Open Access Journal of Agricultural Research}
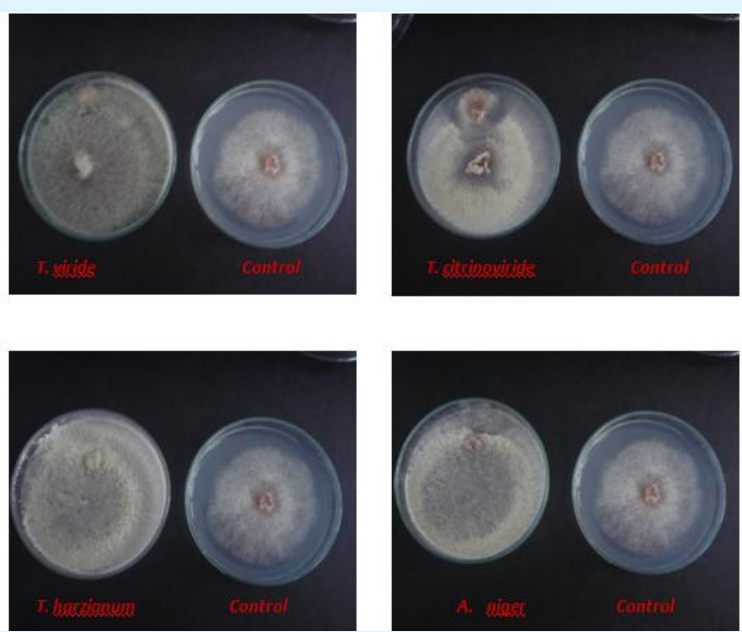

Figure 1: In vitro antagonisms study of fungal strains isolated from tea soil against the tea root pathogen (F.lamoensis).

\section{Growth Promotion and Disease Suppression under Nursery Conditions}

For this experiment pathogen Fomes lamoensis was grown in $100 \mathrm{ml}$ of Potato dextrose broth (PDB). After 10 days of growth the broth was homogenized with the help of a mixer grinder. Homogenized suspension was then diluted 5 times with sterile distilled water for inoculation of soil containing one year old TV1 clonal tea plants.

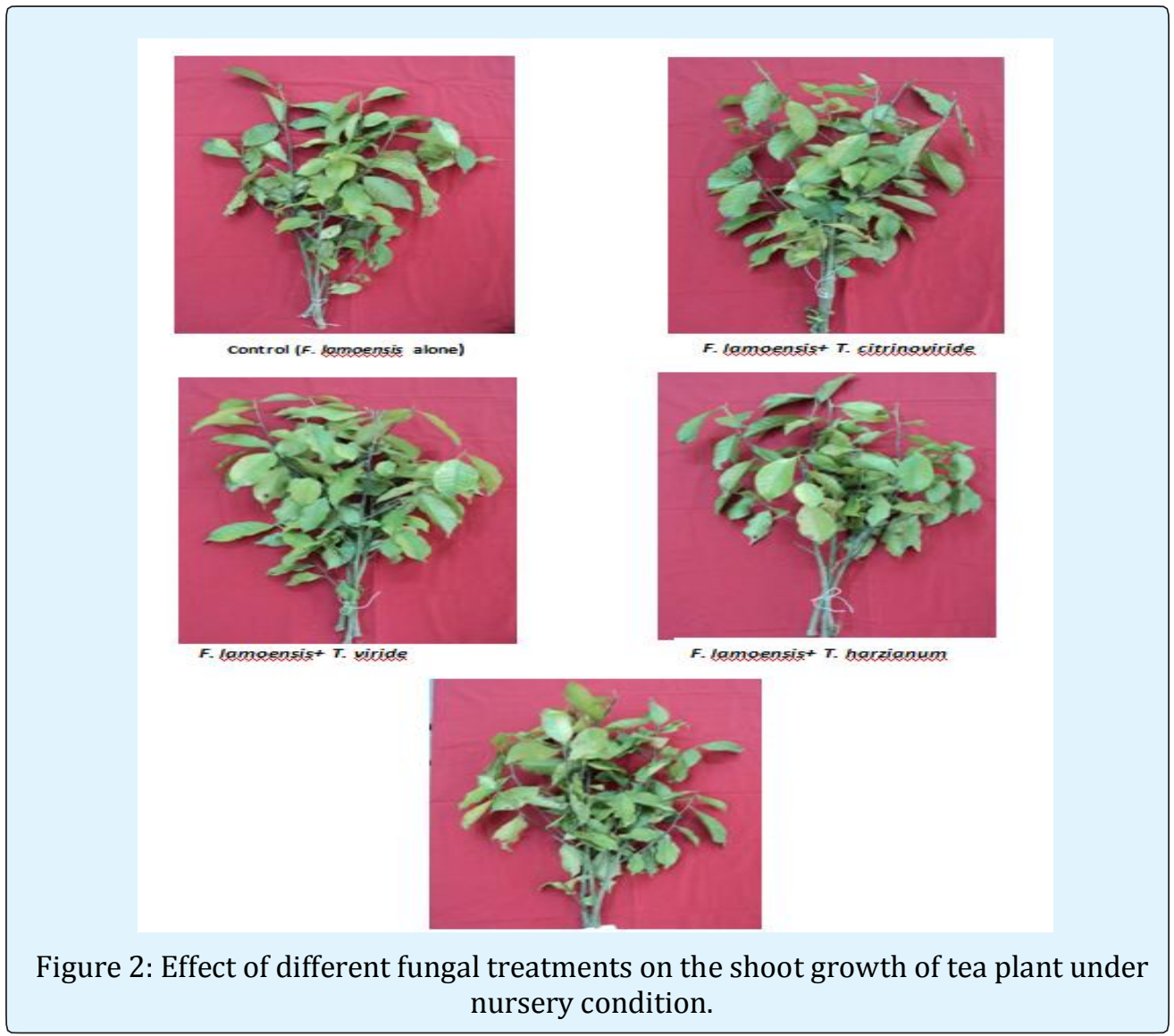

Morang P, et al. Growth Promotion and Biocontrol Potential of Some Isolated Soil Fungi against Brown Root Rot (Fomes Lamoensis) Disease of Tea in Barak Valley of Assam India. J Agri Res 


\section{Open Access Journal of Agricultural Research}

Tea plants were planted in pots containing field soil and farm yard manure (3:1) and were maintained under nursery conditions. The experiment was composed of five different treatments which were as follows: i) Fomes lamoensis alone (Control), (T1) ii) $F$. lamoensis+ Trichoderma citrinoviride (T2), iii) F. lamoensis $+T$. Viride (T3), iv) F. lamoensis + T. harzianum (T4) and v) $F$. lamoensis + Aspergillus niger (T5). The experiment was laid out in completely randomized design (CRD) with three replications and each replication having 5 numbers of tea plants. The experiment was continued for 120 days. After end of the experiment different parameters for the assessment of disease on the basis of disease index computed taking into account on above ground symptoms (leaf drying followed by shredding and drying of whole plants and growth (number of new leaves, number of lateral branches, shoot height, root length, dry weight of shoot, dry weight of root) were recorded.

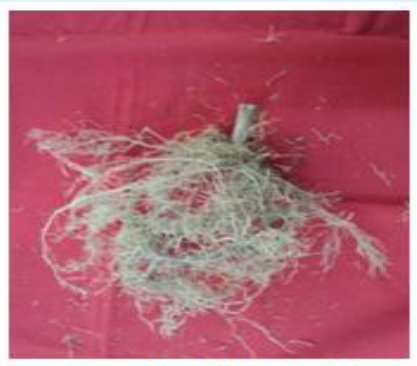

Control (F. lamgensis alone)

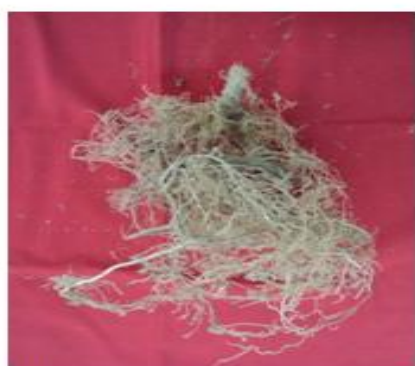

F. lamgensis $+T$. viride

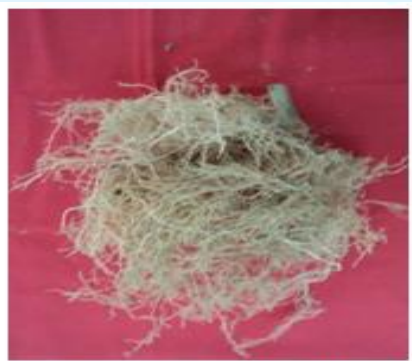

F. lamoensis $+T$. citringviride

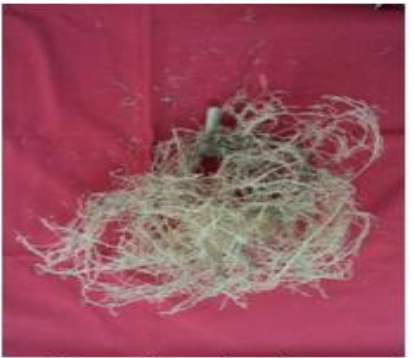

F. lamoensis+ T. haczianum

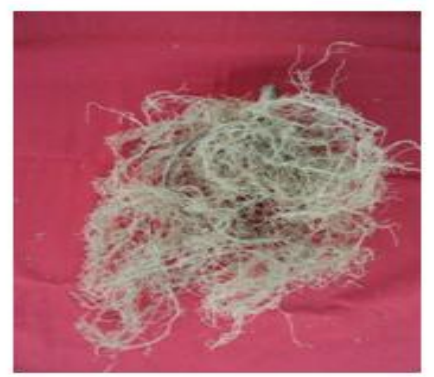

Figure 3: Effect of different fungal treatments on the root length/growth of tea plants under nursery condition.

\section{Statistical Analysis}

All the data were expressed as the mean \pm standard error. Data obtained were subjected to various statistical methods of analysis as given by Gomez \& Gomez [16]. Significant differences between the results were calculated by analysis of variance (ANOVA). Differences at $\mathrm{p}<0.05$ were considered to be significant.

\section{Results}

\section{Antagonism Study of Fungal Isolates}

The antagonistic interaction between the colonies of the pathogen Fomes lamoensis and soil fungi like Penicillium sp Aspergillus sp, Trichoderma viride, Trichoderma citrinoviride was observed. 


\section{Open Access Journal of Agricultural Research}

All the test fungal isolates except Penicillium sp grew close to the pathogen colony and eventually overgrew on it. However, no clear inhibition zone was observed in between the isolates and $F$. lamoensis. The genus Trichoderma showed ' $F$ ' type of colony interaction (Table 1).

\begin{tabular}{|c|c|c|c|c|}
\hline Name of the fungi & \multirow{2}{*}{ Colony interaction } & \multicolumn{3}{|c|}{ Radial growth of $\boldsymbol{F}$. lamaoensis $(\mathbf{c m})$ against the fungal } \\
isolates
\end{tabular}

Values are Mean of three replication \pm SE

$\mathrm{E}-$ The antagonist inhibited the growth of the test pathogen at a particular point $\mathrm{F}$ - Overgrown by the antagonist, I - No inhibition

Table 1: Effect of fungal isolates (antagonists) on the growth and colony interaction of F. lamoensis in dual cultures on PDA.

From the results, it was also observed that the radial growth of $F$. lamoensis was inhibited mainly by $T$. viride $(0.93 \mathrm{~cm})$ followed by T. citrinoviride $(1.66 \mathrm{~cm})$ and $A$. niger (4.06) (Table 8). The inhibitory effect of all the isolates were found to be statistically significant at $\mathrm{P} \leq 0.05$ level over their respective controls. Isolates of Penicillium sp however, have been found to be having no significant effect on the radial growth of $F$. lamoensis. (Plate 1 ).

\section{Disease Control and Growth Promotion (Percent Disease Incidence and Disease Control)}

From the disease assessment study it was observed that in pathogen alone (F. lamoensis) treated tea plants (control), Leaf drying to drying of plants occurred from 30th day and 120th day onwards.

\begin{tabular}{|c|c|c|c|c|c|c|c|}
\hline \multirow[b]{2}{*}{ Treatment } & \multicolumn{3}{|c|}{ Leaf Drying } & \multicolumn{3}{|c|}{ Leaf shedding } & \multirow[b]{2}{*}{$\begin{array}{c}\text { Drying of tea } \\
\text { plants }\end{array}$} \\
\hline & 1 leaf & 2 leaf & $\begin{array}{c}\text { More than } 2 \\
\text { leaves }\end{array}$ & 1 leaf & 2 leaf & $\begin{array}{c}\text { More than } 2 \\
\text { leaves }\end{array}$ & \\
\hline T1 (Control) & 30th Day & 38nd Day & 59th Day & 36 th Day & $53^{\text {th }}$ Day & 60th Day & 120th Days \\
\hline $\mathrm{T} 2+$ F. Lamoensis & $51^{\text {th }}$ Day & $63^{\text {th }}$ Day & - & 79th Day & - & - & - \\
\hline $\mathrm{T} 3+$ F. Lamoensis & 60"th Day & - & - & 95 th Day & - & - & - \\
\hline $\mathrm{T} 4+$ F. Lamoensis & $45^{\text {th }}$ Day & $8^{\text {th }}$ Day & - & 90"th Day & $105^{\text {th }}$ Day & - & - \\
\hline
\end{tabular}

Table 2. Effect of different treatments on the development of symptoms of brown root rot disease of tea at different intervals of times.

While plants treated with antagonistic fungi with the pathogen initially showed drying of leaves, which occurred on the 51th, 60th and 45th days respectively but no record were found for drying of tea plants till the end of observation (Table 2).

Under nursery conditions the highest incidence of disease $(53.33 \%$ ) was observed in the plants treated with the pathogen F. lamoensis, on 120th day after inoculation. On the other hand, plants treated with biocontrol fungi (BCF) besides the pathogen showed minimum disease incidence i.e. F. lamoensis +T. citrinoviride (T2) (20\%),

\begin{tabular}{|c|c|c|}
\hline Treatment & $\begin{array}{c}\text { \% Disease } \\
\text { incidence }\end{array}$ & \% Disease control \\
\hline T1 & 53.33 & 0 \\
\hline T2 & 20 & 80 \\
\hline T3 & 13.33 & 86.67 \\
\hline T4 & 13.33 & 86.66 \\
\hline TS & 33.32 & 66.66 \\
\hline
\end{tabular}

Table 3. Effect of different fungal treatments on the Disease development and disease control (120 days after treatment). 


\section{Open Access Journal of Agricultural Research}

F. lamoensis +T. viride (26.66\%), F. lamoensis+ T. harzianum $(13.33 \%)$ and F. lamoensis + A. niger (66.66 \%) respectively (Table 3).

Highest disease control was recorded $(86.67 \%)$ in the treatment $\mathrm{F}$. lamoensis+ $\mathrm{T}$. harzianum followed by $\mathrm{F}$. lamoensis $+\mathrm{T}$. viride $(86.66 \%)$, and $\mathrm{F}$. lamoensis+ T.citrinoviride respectively. While least disease control was observed in the plants treated with F. lamoensis+ A. niger $(66.6 \%)$ (Table 3$)$.

\section{Effect of Different PGPF's on Growth of Tea Plants}

Highest shoot height $(48.23 \mathrm{~cm})$ was recorded when plants were treated with T4 (F. lamoensis $+\mathrm{T}$. harzianum). It was followed by $\mathrm{T} 2$ (F. lamoensis+ $\mathrm{T}$. citrinoviride) $(47.23 \mathrm{~cm}), \mathrm{T} 5$ (F. lamoensis+ A. niger) $(47.06 \mathrm{~cm})$ and T3 (F. lamoensis+ T. viride) $(44.96 \mathrm{~cm})$.

\begin{tabular}{|c|c|c|}
\hline Treatment & Number of new leaves & Number of lateral branches \\
\hline T1 & $20.00 \pm 2.08$ & $2.33 \pm 0.88$ \\
\hline T2 & $24.66 \pm 0.88$ & $4.30 \pm 0.88$ \\
\hline T3 & $22.00 \pm 1.00$ & $3.67 \pm 0.67$ \\
\hline T4 & $21.66 \pm 3.17$ & $6.67 \pm 0.89$ \\
\hline T5 & $22.67 \pm 1.45$ & $3.32 \pm 0.87$ \\
\hline LSD at 5\% level & 0 & 1.42 \\
\hline
\end{tabular}

Table 4: Effect of different fungal treatments on the number of new leaves and lateral branches (120 DAT).

The control sets showed lowest shoot height and root length. Maximum (22.31\%) percent increase over control was recorded in the treatment $\mathrm{T} 4$ (F. lamoensis $+\mathrm{T}$. harzianum) and minimum (13.99\%) in the treatment $\mathrm{T} 3$ (F. lamoensis+ T. viride). Similarly, maximum (36.47\%) percent increase in root over control was recorded in $\mathrm{T} 5$ (F. lamoensis+ A. niger). The treatment T4 (F. lamoensis + T. harzianum) however exhibited minimum (9.80\%) percent increase in root length (Table 4).

On the other hand, parameters such as the number of new leaves and lateral branches of tea plants, percent increase over the control in the number of new leaves) were recorded to be the highest $(23.30 \%)$ in the treatment T2 (F. lamoensis+ T. citrinoviride) followed by T5 (F. lamoensis+ A. niger) (13.33\%), T3 (F. laomensis+ T. viride) $(10.00 \%)$ and $\mathrm{T} 4$ (F. lamoensis $+\mathrm{T}$. harzianum) $(8.30 \%)$ respectively. Highest per cent increase (186.26\%) over control in the number of lateral branches was recorded in case of the $\mathrm{T} 4$ ( $\mathrm{F}$. lamoensis $+\mathrm{T}$. harzianum) and lowest (57.51\%) in case of treatment $\mathrm{T} 3$ (F. laomensis+ T. viride) (Table 5).

\begin{tabular}{|c|c|c|c|c|}
\hline Treatment & Shoot height $\mathbf{c m})$ & Root length $\mathbf{( c m )}$ & $\begin{array}{c}\text { Shoot height \% increase over } \\
\text { control }\end{array}$ & $\begin{array}{c}\text { Root length \% increase over } \\
\text { control }\end{array}$ \\
\hline T1 & $39.43 \pm 3.58$ & $21 \pm 2.34$ & & 17.76 \\
\hline T2 & $47.23 \pm 3.06$ & $24.73 \pm 2.43$ & 19.78 & 28.38 \\
\hline T3 & $44.96 \pm 5.45$ & $26.96 \pm 1.83$ & 13.99 & 9.8 \\
\hline T4 & $48.23 \pm 0.87$ & $23.06 \pm 0.71$ & 22.31 & 36.47 \\
\hline T5 & $47.06 \pm 1.56$ & $28.66 \pm 4.88$ & 19.35 & \\
\hline LSD at 5\% level & 6.28 & 5.31 & & \\
\hline
\end{tabular}

Table 5: Effect of different fungal treatments on the tea shoot height and root length (120 DAT).

\section{Effect of Different PGPF's on the Biomass of Shoot}

Highest shoot fresh weight of $8.62 \mathrm{~g}$ was recorded in $\mathrm{T} 2$ (F. lamoensis+ T. citrinoviride) followed by $8.08 \mathrm{~g}$ in T4 (F. lamoensis+ T. harzianum), $7.99 \mathrm{~g}$ in $\mathrm{T} 3$ (F. lamoensis+ T. viride) and $7.18 \mathrm{~g}$ in $\mathrm{T} 5$ (F. lamoensis $+A$. niger) antagonistic fungi treated tea plants. Lowest fresh weight of shoot was recorded in the untreated control T1 $(F$. lamoensis alone) (Table 6). 


\section{Open Access Journal of Agricultural Research}

\begin{tabular}{|c|c|c|c|c|}
\hline Treatment & $\begin{array}{l}\text { Fresh weight of } \\
\text { shoot (g) }\end{array}$ & $\begin{array}{l}\text { Dry weight of } \\
\text { shoot }(\mathrm{g})\end{array}$ & $\begin{array}{c}\text { Fresh wt. of shoot \% increase } \\
\text { over control }\end{array}$ & $\begin{array}{l}\text { Fresh wt. root \% increase over } \\
\text { control }\end{array}$ \\
\hline T1 & $6.76 \pm 0.69$ & & $2.65 \pm 0.31$ & \\
\hline T2 & $8.62 \pm 0.93$ & $3.19 \pm 0.32$ & 29.23 & 20.37 \\
\hline T3 & $7.99 \pm 1.28$ & $2.81 \pm 0.36$ & 18.19 & 6 \\
\hline $\mathrm{T} 4$ & $8.08 \pm 0.84$ & $3.22 \pm 0.40$ & 19.52 & 21.5 \\
\hline T5 & $7.18 \pm 0.36$ & $2.68 \pm 0.19$ & 6 & 1.13 \\
\hline $\begin{array}{c}\text { LSD at } 5 \% \\
\text { level }\end{array}$ & 1.93 & 1.06 & & \\
\hline
\end{tabular}

Table 6: Effect of different fungal treatments on the fresh and dry weight of tea shoots (120 DAT).

In the pathogen infested plants treated with BCF, highest dry weight of shoot was recorded in $\mathrm{T} 2(F$. lamoensis+ T. citrinoviride) (3.19 g) followed by T4 $(F$. lamoensis+ T. harzianum) (3.22 g), T3 (F. lamoensis $+T$. viride) (2.81g) and T5 (F. lamoensis + A. niger) (2.68 g) respectively. Lowest dry weight accumulation was recorded in the control $\mathrm{T} 1$ ( $F$. lamoensis alone) $2.65 \mathrm{~g}$ (Table 6).

Among all the treatments it was observed that the treatment $\mathrm{T} 2$ (F. lamoensis+ T. citrinoviride) showed the highest percent increase over the control of fresh weight
(29.23\%) and in dry weight of the shoot treated plants T4 (F. lamoensis+ T. harzianum) (21.50\%).

\section{Effect of different PGPF's on the biomass of root}

Highest root fresh weight of was registered in the treatment $\mathrm{T} 2 \quad(F$. lamoensis+ $T$. citrinoviride) $(8.74 \mathrm{~g})$ followed by T3 (F. lamoensis $+T$. viride $)(7.99 \mathrm{~g})$, T4 $(F$. lamoensis+ T. harzianum) $(7.11 \mathrm{~g})$ and $\mathrm{T} 5$ (F. lamoensis + A. niger) (6.41g) respectively. Lowest biomass of root was recorded in the untreated control T1 (F. lamoensis alone) (4.42 g) (Table 7).

\begin{tabular}{|c|c|c|c|c|}
\hline Treatment & $\begin{array}{c}\text { Fresh weight of } \\
\text { root (g) }\end{array}$ & Dry weight of root (g) & $\begin{array}{c}\text { \% increase over control on } \\
\text { fresh weight of root }\end{array}$ & $\begin{array}{c}\text { \% increase over control } \\
\text { on dry weight of root }\end{array}$ \\
\hline T1 & $4.42 \pm 0.23$ & $2.19 \pm 0.07$ & & \\
\hline T2 & $8.76 \pm 0.40$ & $3.91 \pm 0.19$ & 98.19 & 78.53 \\
\hline T3 & $7.99 \pm 0.28$ & $3.65 \pm 0.08$ & 80.76 & 66.66 \\
\hline T4 & $7.11 \pm 0.50$ & $3.81 \pm 0.25$ & 60.85 & 73.97 \\
\hline T5 & $6.41 \pm 0.77$ & $3.23 \pm 0.40$ & 45.02 & 47.48 \\
\hline LSD at 5\% level & 1.05 & 0.54 & & \\
\hline
\end{tabular}

Values are Mean \pm SE from three sets each.

Table 7: Effect of different fungal treatments on the fresh and dry weight of root (120 DAT).

In the dry weight of root highest dry matter accumulation was recorded in the treatment $\mathrm{T} 2(F$. lamoensis $+T$. citrinoviride) (3.91g) followed by T4 (F. lamoensis + T. harzianum) (3.81 g), T3 (F. lamoensis + T. viride) (3.65g) and T5 (F. lamoensis + A. niger) (3.23 g) respectively in BCF treated plants. Treatment Control T1 (F. lamoensis alone) was observed to have the lowest dry root matter accumulation ( $2.19 \mathrm{~g})$ (Table 7).

Highest fresh weight of root, and the percent increase over control was recorded in the treatment T2 (F. lamoensis + T. citrinoviride) $(98.19 \%)$ and lowest was in T5 (F. lamoensis +A. niger) (45.02\%). It was observed that highest dry weight of root, the percent increase over the control recorded in $\mathrm{T} 2$ (F. lamoensis+ $\mathrm{T}$. citrinoviride)
(78.53\%) whereas lowest was recorded in the treatment T5 (F. lamoensis +A. niger) (47.48\%).

\section{Discussion}

The control of soil borne plant pathogens using antagonists has gained momentum in recent years. In vitro screening of organisms is a valuable tool to select the potential strains of bio-control agents [17-21]. The results of the in vitro studies showed that the fungal antagonist $\mathrm{T}$. viride most effectively inhibited the radial growth of F. lamoensis. Antagonist when applied into the soil might destroy pathogen inoculums, prevent recolonization of treated soil by the pathogen or protect germinating seeds and roots from infection. Most of the 


\section{Open Access Journal of Agricultural Research}

soil fungi isolated from the tea agro ecosystem are known to survive saprophytically in nature [22]. Release of inhibitory substances/metabolites by Trichoderma viride into the host organism may directly inhibited the growth of the pathogen by disintegrating the hyphal wall resulting in the penetration, absorption and lysis of the mycelium [8,23]. The results of the in vitro antibiosis study expressed good inhibitory effect against the tea root pathogen F. lamoensis (Fig. 1, 2 \& 3). Depletion of nutrients and release of inhibitory substances (antibiotics) by the fungi are known to play a major role in antagonism and these factors are known to be mainly governed by the physico-chemical properties of the environment [24]. Members of Trichoderma sp are known to be active hyperparasites of several soil fungi and hence it is used as a biocontrol agent [25]. Control of plant diseases by the use of antagonistic microorganisms can be a effective means has been suggested by some workers $[19,26]$.

The result of the nursery experiment showed that tea plants inoculated only with the pathogen, F. lamoensis exhibited the highest incidence of disease while lowest was recorded in plants treated with antagonistic fungi besides the pathogen. Besides controlling the disease, the antagonistic fungi also enhanced the growth of the tea plants. The number of new leaves, lateral branches, shoots height, root length, fresh weight of shoot and root and dry weight of shoot and root increased significantly over the control. Plant diseases have successfully been controlled by using bacterial and fungal antagonists [27]. Tea root rot fungus F. lamoensis can be controlled as well as yield recovery have done successfully by using bacterial strains i.e. B. subtilis and P. aeroginosa [28]. Introduction of the antagonists i.e. T. harzianum and $\mathrm{T}$. koningii in the field soil for controlling S. rolfsii causing foot rot disease of soya bean, and other crops have been reported by Dutta, and Dutta and Deb $[17,26]$. Most of the early works on the biocontrol of plant pathogen by Trichoderma spp. involved the direct ability of this fungi to interact with the soil pathogens [29]. The results obtained in the present work are the similar to Trichoderma and Sebacinales, species inoculation which induced root and shoot growth in Piper dilatatum $[10,12,30-34]$.

The result presented here indicate the possibility of controlled the primary root disease i.e. brown root rot which is very prevalent and severe in the region of Barak valley of Assam, India. Further field trials are needed to ascertain the consortia of antagonistic fungi as disease control tools in different soils and different environmental conditions. In view of sustainability, using of these beneficial fungi definitely will help the tea planters at large.

\section{Acknowledgment}

The author thank to Dr Gunindra Das, Principal, PDUAM, Tulungia, Bongaigaon and University Grant commission, New Delhi, for providing financial assistance.

\section{References}

1. Banerjee B (1993) Tea production and processing. Oxford and IBH Publishing Company Pvt Ltd New Delhi.

2. Satyanarayana G (1980) Benefit evaluation of soil fumigation in root rot control in tea in NE India. Two and a Bud 27(2): 63-64.

3. Barthakur BK (2011) Recent approach to Tocklai to plant protection in tea in North East India. Science and Culture 77(9-10): 381-384.

4. Bale JS, van Lenteren JC, Bigler F (2008) Biological control and sustainable food production. Philos Trans R Soc Lond B Biol Sci 363(1492): 761-776.

5. Raaijmakers JM, Vlami M, Souza JT De (2002) Antibiotic production by bacterial biocontrol agents. Anton van Leewenhoek 81(1-4): 537-547.

6. Kloepper JW (1993) Plant growth promoting rhizobacteria as biological control agents. Soil microbiological techniques pp: 255-274.

7. Baker KF, Cook RJ (1974) Biological control of plant pathogens. Biological control of plant pathogens pp: 433.

8. Chet I, Benhamou N, Haran S (1998) Mycoparasitism and lytic enzymes. Trichoderma and Gliocladium 2: 153-172.

9. Harman G, Shoresh M (2007) The mechanisms and applications of opportunistic plant symbionts. Novel Biotechnologies for biocontrol Agent Enhancement and Management pp: 131-155.

10. Harman GE, Howell CR, Viterbo A, Chet I, Lorito M (2004) Trichoderma species-Opportunistic, avirulent plant symbionts. Nat Rev Microbiol 2(1): 43-56. 


\section{Open Access Journal of Agricultural Research}

11. Vinale F, Sivasithamparam K, Ghisalberti EL, Marra R, Woo SL, et al. (2008) Trichoderma - Plant pathogen interactions. Soil Biol Biochem 40(1): 1-10.

12. Harman GE, Petzoldt R, Comis A, Chen J (2004) Interaction between Trichoderma harzianum strain T22 and maize inbred line Mo17 and effects of this interaction on diseases caused by Pythium ultimum and Colletotrichum graminicola. Phytopathol 94(2): 147-153.

13. Viterbo A, Montero M, Ramot O, Friesem D, Monte E, et al. (2002) Expression regulation of the endochitinase chit36 from Trchoderma asperellum (T. harzianum T-203). Curr Genet 42(2): 114-122.

14. Zeilinger S, Galhaup C, Payer K, Woo SL, Mach RL, et al. (1999) Chitinase gene expression during mycoparasitic interaction of Trichoderma harzianum with its host. Fungal Genet Biol 26(2): 131-140.

15. Yedidia I, Benhamou N, Chet I (1999) Induction of defense responses in cucumber plants (Cucumis sativus L.) by the biocontrol agent Trichoderma harzianum. Appl Environ Microbiol 65(3): 10611070.

16. Gomez KA, Gomez AA (1984) Statistical Procedures for Agricultural Research. John Wiley and Sons Publication, New York.

17. Dutta BK (1981) Studies on some fungi isolated from the rhizosphere of tomato plants and the consequent prospect for the control of Verticillium wilt. Plant soil 63(2): 209-216.

18. Cirvilleri G, Catara V, Bella P, Marchese E (1999) Isolation and characterization of rhizosphere bacteria of potential interest for biological control of soilborne pathogens. Phytophaga Suppl IX: 79-87.

19. Cook RJ (1993) Making greater use of introduced microorganisms for biological control of plant pathogens. Ann Rev Phytopath 31: 53-80.

20. Sarkar S, Narayanan P, Divakaran A, Balamurugan A, Premkumar R (2010) The in vitro effect of certain fungicides, insecticides, and biopesticides on mycelial growth in the biocontrol fungus Trichoderma harzianum. Turk J. Biol 34: 399-403.

21. Morang P, Dutta BK, Ranjita I, Dileep Kumar BS (2012) Antagonistic potential of some isolated soil fungi against brown root rot disease of tea in Barak valley of Assam. J Pure Appl Microbiol 7(1): 711-716.

22. Deb PR, Dutta BK (1991) Sudies on biological control of foot rot disease od soyabean caused by Sclerotium rolfsii Sacc. J Plant disease Protect 98(5): 539-546.

23. Chen J, Harman GE, Conis A, Cheng -Wu G (2005) Proteins related to the biocontrol of Pythium damping off in maize with Trichoderma harzianum Rifai. J Integ Plant Biol 47(8): 988-997.

24. Burgess LW, Griffin DM (1967) Competitive saprophytic colonizarion of wheat straw. Ann Appl Biol 60(1): 137-142.

25. Ekefan EJ, Jama A, Gowen SR (2009) Potential of Trchoderma harzianum isolates in biocontrol of Colletotrichum capsici causing anthracnose of pepper (Capsicum spp.) in Nigeria. J Appl Biosci 20: 11381145.

26. Deb PR, Dutta BK (1988) Trichoderma as biocontrolling agent against $\mathrm{S}$. rolfsii. Microbios Letter 37: 107-113.

27. Campbell R (1989) Biological control of microbial plant pathogens. Cambridge University Press, Cambridge.

28. Morang P, Devi SP, Jha DK, Dutta BK, Dileep Kumar BS (2018) Tea root brown-rot fungus disease reduction and yield recovery with rhizobacteria inoculation in both nursery and field trials. Rhizosphere 6: 89-97.

29. Shoresh M, Harman GE (2008) The relationship between increased growth and resistance induced in plants by root colonizing microbes. Plant Signaling Behav 3(9): 737-739.

30. Barazani O, Benderoth M, Groten K, Kuhlemeier C, Baldwin IT (2005) Piriformospora indica and Sebacina vermifera increase growth performance at the expense of herbivore resistance in Nicotiana attenuata. Oecol 146(2): 234-243.

31. Harman GE (2000) Myths and dogmas of biocontrol. Changes in perceptions derived from research on Trichoderma harzianum T-22. Plant Dis 84: 377-393.

32. Harman GE, Bjorkman T, Ondik K, Shoresh M (2008) Changing paradigms on the mode of action and uses of Trichoderma spp. for biocontrol. Outlooks pest Manag 19: 24-29.

Morang P, et al. Growth Promotion and Biocontrol Potential of Some Isolated Soil Fungi against Brown Root Rot (Fomes Lamoensis) Disease of Tea in Barak Valley of Assam India. J Agri Res Copyright $($ Morang P, et al. 2018, 3(5): 000173. 


\section{Open Access Journal of Agricultural Research}

33. Peskan-Berghoefer T, Shahollari B, Giong PH, Hehl S, Markert C, et al. (2004) Association of Piriformospora indica with Arabidopsis thaliana roots represents a novel system to study beneficial plant-microbe interactions and involves early plant protein modifications in the endoplasmic reticulum and at the plasma membrane. Physiol Plant 122(4): 465-477.
34. Rai M, Acharya D, Singha A, Verma A (2001) Positive growth responses of the medicinal plants Spilanthes calva and Withbania somnifera to inoculation by Piriformospora indica in field trial. Mycorrhiza. 11(3): 123-128.

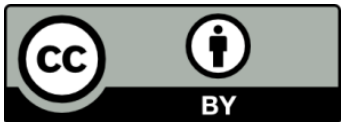

